SECTION 29. Literare. Folklore. Translation Studies.

Aslanova Khafiza Abdurakhimova

$\mathrm{PhD}$ student of the Samarkand State University

\title{
WHAT IS THERE IN THE PEN NAME OF POET GADOIY?
} Gadoiy.

The article raises a question of life and creativity of the great poet

Keywords: Gadoiy, IX and X centuries.

Firstly, well known Turkish poet Mukhammad Fuod Konrulu in 1914 in his article Đokurucu ve onuncu asirlerdaki Çagatay sairleru" (Poets of Chagatay in the IX and X centuries) [3] which was written on the basis of Navoi's Muxokamatul-lugatayn" (Discussion of two languages) gave some information about Mavlono Gadoiy. Besides this M.Fuat Koprulu in the book titled as Islam Ansiklopedis" (Wikipedia of Islam) published his article Chagatay literature" in which he wrote:

The main intension was verifying the names Gadoiy" and Gado (Bagger) and distinguish the differences between them. He wrote that he didn't share the idea of being that well known and intelligent poet the same person who was called Gadoiy or Gado The word Gado" is translated as bagger" "Gadoiy" means a person who takes after bagger" Perhaps in 1490 or in 1491/149290 year old Gadoiy was still alive. As it was mentioned by Navoiy that poet made his creative activity in Chagatay Language and his activity was in bloom in Obul-Kosim Bobur's time. Navoiy points at that person in the chapter dedicated to above mentioned man. In the period wen Navoiy was performing his activity on writing his -Majolisan-nafois" (Elegent takings) poet Gadoiy was still alive. It the beginning of the article the aim of choosing that pen name was noted and it was said had been done it under the influence of Sufiy tendencies, and connected with principles of mode of living that is said to be one of forms of existence. Such kind of view point of Sufiy's beliefs makes me verify such kind of artistic attitude towards those thoughts.

According to E.Akhmadkhojaev the Etymology of this pen name tells us that this man belongs to ordinary people he's industrious, in general, he's a representative of men living at that period [1, p. 14]. And we agree about these two standpoints Owing to Konrulus opinion Godiy was a successor of Sufi dynasty. His gazel written in Persian was mentioned in Radoif ul-ashor" (Rhymed verses) by Fakhri Khirrotiy. It shows that Godoiy was a member of Naqshbandiya trend. Besides, this E.Akhmadkhojaev notices that pen name has the meaning of poor, a man of no fortune. This idea found its proof in translation info Persian done by Khakimshokh Mukhammad Kazbiniy and it was included 
into -Graceful meetings" Gadoiy wrote It I come to your door to ask for mercy and alms" [2, p. 258]. Then he says The reason of chasing this pen name by the poet was firstly because of his belonging to Sufi philosophy friend, and at second his coming out from lower layer, plain, ordinary people. And then perhaps poet's being fan of love, adornment also influenced on taking this pen name. Akhmadkhojaev came to such conclusion, on analyzing the below given poetic lines [1, p. 34].

Agar sen husn elining xonidursen,

Jahonda dog 'i mendek bir Gado yo 'q.

Gadoiy besh emastur, der raqibing,

Gadodurmen, vale, sultondin ortuq.

And if you are a crowned king of men of beauty

There's no bagger like me in the world, I'm the only [4, p. 124].

Your rival says Gadoiy, you 're man of good for nothing

I'm a bagger, yet, worthier than Sultan in everything [4, p. 125].

Scientist in Turkish literature Alesses Bombachi had his (History of Turkish literature) published in 1959 and among other poets who lived before Navoi was the name of Gadoiy, the name only without giving any explanation of that pen name. among foreign scientists who gave much more information about Gadoiy was Ya.Ekman the find more factual details about the poet in his research works.

He wrote his poems by the pen name of Gadoiy, later he used the word Gado". Navoi called him Mavlono Gadoiy, they all were in the rank of Chagatay poets His real name was nowhere mentioned. And we have very little information about his life. Navoi in his work -Graceful talks" in pare III wrote that Gadoiy was loud in praises in Abdulkosim Bobur's time, though he was 90 years old, he continued to live a real life on the Earth. As Graceful Talks" appeared in 897/1491-92 the can say that Gadoiy's birth year was in 807/140405 .

The poet himself confirmed that Navoi's information was true indeed, as he freely lived more than 90 years.

In the bellow given lines Gadoiy compares his old age with long black hair of his mistress, he writes that she is a pledge of his longest life. As it is said long black hair was taken as a symbol of long life.

Ul qaro soching sening umri darozimdur mening, Necha qilg 'aysen kishi umrini mundoq poymol"

That long black hair of yours as long as mine old age 
And why you should make it short, without grace.

And Turkish scientist on Navoi's literary activity in his four volume book in the first volume wrote about Navoi's life, art and his being man of men, and there mentioned the period of time in which the poet lived.

Sometimes it goes without saying some information became the subject of discussion, for example why Devon of Gadoiy and Divan of Lutfiy were covered together.

E.Akhmadkhodjaev wrote about that case the fallowing:

"Gadoiyning devoni Lutfiy devoni bilan birga kitobat qilinganligi uchun biz Lutfiy devoniga Gadoiy g'azallaridan kirib qolganmikin degan mulohaza bilan Lutfiyning devonini ham ko'zdan kechirdik. Ammo, gumonimiz isbotlanmadi".

- We were in doubt on solving that problem we thought that Some gazels of Gadoiy could be entered Lutfiy's Divan.

It is true that Mavlono Gadoiy and Mavlono Lutfiy were representatives of the same literary atmosphere and did their activities being in contact. Gadoiy wrote about it the fallowing lines:

Gar inoyat bo 'lsa haqdin, dag 'i sultondin nazar,

Bu Gadodek Lutsfiy kim bo 'lg 'ayki, Salmon bo 'Imag 'ay.

If one is worthy of being shown respect by Sulton

It would be me who's not second to Lutfiy and Salman [4, p. 153].

From above mentioned verse the came it conclusion that both of them were companions, supported each other. In that above mentioned gazel Gadoiy complains of his life and expects that some merciful deeds will be shown to him as he can stand in the same rank where Lutfiy and Salmon Savajiy stand being talented and comparable with them.

9 gazels and also 197 gazels, one madrigal, 2 poetic jenre Aruz called -mstahzod" and -quitars" were written by the pen name of Gadoiy some poems were written under the pen name Gado". But 28 gazels were written without mentioning pen name the pen name of the poet accurse in this gazels.

Gadoiy's meaningful, joyous, multicolored lyric legacy, without doubt, were created by him during his long life, the life that continued nearly a century.

As a proof we can give professor Khamid Sulayman's words: As we know there was not such way of noting the period of time under the poem in the literary of Oriental history. Even in the poems which were written with hand wring of a poet himself, in autographs you can't find information which shows the time of a poem were written. Poets been satisfied on showing, writing their names, or pen names of the last lines of a gazel" [1, p. 22]. 
In conclusion we can say that pen name of Gadoiy" is based on 3, in our opinion more true supposition. These are: living a life of a bagger, begging for love from human being (home mistress, beloved one), appealing for love and belief of God. We came to this conclusion relying on the period the poet lived, in the contents of his Lymoe poems. Turning to the poets life and his literary activity we find out some information about that passed time. It serves us as source.

Gadoy's poetry is valued high owing to arooz genre which was skillfully used by the poet, as such kind of poetry writing became popular in XV century. Itis said that arooz genre made notable influence on the development of the Turkish Language, and Mavlono Gadoiy's literery activity was not at all worse in making impotance than other poets deeds. As we know in history of Khuroson and Mavounahr in Temur and Timurids time" such tendency as laying claim to getting rid of feodals' oppression, feodals' attampts to be rulers of the position and preserve that post as long as they could, to form and maintain the national literature, culture were common with men of letter, even with Temurids". [7, p. 30].

Owing to these stand points and requirements of time a lot of men of pen, poets appeared in Temurids' reigning period. And in the second part of XIV century science, culture, art together with world literature Turkish poetry also took its shape, started winning praises and indeed. At the end of XV century and further Uzbek poetry rose to the highest point. From that very time Turkish poetry becoming mighty and colorful could be rivals to Persian - Tajik poetry. We can't imagine Uzbek poetry which became worthy and well known if we leave alone such classic poets as Sakkokiy, Lutfiy, Gadoiy and other poets, their literary activies.

Alisher Navoiy the founder of the Uzbek Language and literature noted those above mentioned poets" great contribution to the development of Literature in his book -Muhokamatul-lughatain" (Dictionary of two languages).

Gadoiy tookan active part in the lives of men of literature, made a great influence on creative writings of poets of that time. It goes without saying that Gadoiy's beautiful, fascinating gazels can prove our opinion, as his gazels are esteemed, valued high thanks to their being grandious, melodious, meaningful. From point of their form and sound, from social and political, aethetic, educational, historical points they were well done Gadoiy's gazels are manifold, beautifully colored, rich in contents. The poet showed his altitude towards various historical events, human beings' lives, their descords, motives and reasons of people's complements. And indeed Gadoiy was an expert in using various forms of gazel genre.

On turning to his gazels we come across with facts concerning the poets life and period of time when he dealt with poetry writing and performed worthy, memorial acts. 
Aroor is a complicated genre but at the same time very beautiful form of Oriental versification Arooz genre is based on alternation of long and short syllables and grouped in particularly form in the line. Two lines of gazel are called a bite" Gazels can have 5, 7, 9, 11 or more bites. At the and of the gazel, in the last but one line the auther gives his name.

Uzbek classical poet Zahiriddin Bobur verified 21 types of bahr" (arooz writing forms) which include 534 forms of meter and rhythm. Only 11 are used in Uzbek arooz

Example:

Sarvaqtim/izga bir gu/zar ettihg/ ajab-ajab,

- - V - V - - - V - V -

Nogoh kor /uchidin na/zar ettihg ajab-ajab

- - V - V - - - V - V - [5, p. 22].

Patten

$--V /-V--/--V /-V-\sim$

$-=$ long syllable

$V=$ short syllable

We want you to draw your attention to below given gazel of Gadoiy which belongs to farewell bidding topic and consided to be elegiac.

Komu nokom eshigingdin ketti, ey jon, alvido,

Chun qazodin mundoq ermish hukmu farmon, alvido!

Davlatingdin xush kechurdum muddate umri aziz,

Habbazo ul kom-u zavqu ayshu javlon, alvido!

Bas sudo' erdi fig 'onimdin ulusqa, ey begim:

Mushkil ishni qildim oxir elga oson, alvido!

Jo yi nuning suyi ermish ob-i Kavsar shaksizni,

Ravzayi rizvon dag'i bog 'i Xiyovon, alvido!

Ey darig 'o-kim, tag 'oful birla kechti muncha umr:

Bilmadim qadri Shimoly bog 'i Zog 'on, alvido!

Nechakim, qonimdin ichti su niholi qomating,

Topmadim sendin bar, ey sarvi xiromon, alvido!

Gar Gado bordi eliktin, bok emas, sen yaxshi qol,

Komronlik birla, ey sultoni xubon, alvido! [6, p. 141].

Farewell to hopes which left my heart forever clapping my door, Farewell to life doomed not to go on, be at length any more! 
Of wealth I'd not cared, had a dream of life full of fun and bliss, Farewell to the days brihgt, starut sky them I scarcely saw!

O good lord, how I could dare to force my kin to fuss and moan, Farewell, friends, I myself solved my problems obeying Law!

Waters here are much sweeter than waters in Kavsar river, Farewell to Khiyovon garden as fair as that one in paradise, O!

Alas, I've lived a miserable life not for fuv years indeed, Farewell to Northen Zoghon farden of which not cared before!

My heart did bleed been taken by her furiously beautiful grace, Farewell to my bonny lass, who found me not worthy to adore!

Tho' Gadoiy at his fiftieth he bids thee the warmest farewell, Farewell to my crowned ruler I' $\mathrm{m}$ leaving not to come again $\mathrm{O}$ !

Above given gazels is written in ramali musammani solim bahr, its patten is as fallowing.

$$
\begin{array}{cccc}
\text { Fo-i-lo-tun } & \text { fo-i-lo-tun } & \text { fo-i-lo-tun } & \text { fo-i-lun } \\
-\mathrm{V}-\mathrm{-} & -\mathrm{V}-\mathrm{-} & -\mathrm{V}-\mathrm{-} & -\mathrm{V}-
\end{array}
$$

On making interpretation of this gazel we came to know that there was some discord between poet Gadoiy and the ruler and it such case was held by him and men of ranks. In our opinion he wrote this poem on the eve of his departure. Gadoiy skillfully expresses his love for his country, sings about his troubled state of his soul, about not shared love.

In conclusion we can say that Gadoiy was poet of worth, owner of heart flaming.

\section{REFERENCE}

1. Akhmadkhojaev E. Gadoiy (His life and literary legacy). - T.: Science, 1978.

2. Ali Asqar Khikmat -Graceful talks" from translation into Persian works of Navoi in the XVI century. Tehran, 1945.

3. Faut Kunrulu. Chagatay poets of IX and X century. Furk Yurdi”, seri 1. $1330 / 1914$

4. Handwriting collection. Biblatique Nationale Parij” («Parij Milliy kutubxonasi») «Departament des. Manuscrits Suppl turc» («Turk qo'yozmalari bo'limi») Inv. 981

5. Khojiakhemedov A. A vocabulary of Uzbek aroor. T.: 1998.

6. Pustamov M. A vocabulary of Gadoiy's garels. T.: 1993.

7. Izzat Salton Aovoiy‘s book of heart”. T., 1969. 